\title{
PENGEMBANGAN DAN PENGELOLAAN WAKAF PRODUKTIF
}

\author{
Syuhada' \\ Institut Agama Islam Bani Fattah Jombang, Indonesia \\ syuhada@iaibafa.ac.id \\ Muhammad Misbahul Munir \\ Institut Agama Islam Bani Fattah Jombang, Indonesia \\ syuhada@iaibafa.ac.id
}

\begin{abstract}
Abstrak
Wakaf merupakan salah satu pondasi yang penting untuk membangun kesejahteraan bagi umat Islam, namun jika dicermati lebih mendalam ternyata wakaf pada masa sekarang hanya seperti pasai ditengah masyarakat. Padahal kalau Nazhir atau pengelola dari tanah wakaf tersebut dapat berperan aktif maka tanah wakaf tersebut dapat dijadikan aset sebuah usaha. Dalam pengelolaan daripada tanah wakaf menurut ajaran Islam diserahkan kepada Nazhir. Nazhir tersebut diberikan tugas sebagai pengelola, pemelihara serta sebagai pengurus dari harta wakaf sekaligus sebagai kuasa atas wakaf yang dikelolanya baik di dalam maupun diluar hukum.

Namun dalam penelitian, penulis mendapati ternyata dalam hal pengelolaan dari harta wakaf yang berada di Desa Megaluh terdapat penyelewengan-penyelewengan, hal ini terjadi dikarenakan tidak adanya pengikraran wakaf yang jelas dari wakif terdahulu sehingga ahli waris dari sang wakif merasa bahwa harta wakaf tersebut masih merupakan harta untuk diwaris.
\end{abstract}

Keyword: Pengembangan, Pengelolaan, Wakaf Produktif 


\section{Pendahuluan}

Dalam Islam, wakaf tidak terbatas hanya tempat-tempat ibadah saja dan hal yang menjadi prasarana dan sarananya saja, tetapi diperbolehlan dalam semua macam sedekah. Misalnya, sedekah pada kaum fakir dan orang-orang yang membutuhkannya, memerdekakan hamba sahaya, joint venture yang baik, dan semua kegiatan yang bermaksud mendekatkan diri kepada Allah SWT. ${ }^{1}$

Alasan lain, keberadaan benda yang dimiliki pengelola dalam keadaan wakaf, yang demikian itu tidak dengan mencegah ketetapan hakikatnya, karena Fuqaha' tidak sependapat bahwa benda yang diwakafkan dapat dimiliki. Abu Yusuf, Muhammad Al-Syaibani, dan Mažhab Hanafi menetapkan bahwa benda yang diwakafkan adalah milik Allah SWT. Sementara, Mazhab Mãliki menetapkan bahwa kepemilikan tetap berada pada Wakif. Pendapat ini di dukung Ibn al-Humãm dari Mazhab Hanafi. ${ }^{2}$ Pendapat pertama yang menyatakan bahwa wakaf haruslah bersifat permanen, merupakan pendapat yang didukung oleh mayoritas pendapat 'ulama. Mayoritas 'ulama dari kalangan Syãfi'iyyah, Hanafiyyah, Hanãbilah (kecuali Abu Yusuf dalam suatu riwayat), Zaidiyyah, Ja'fariyyah dan Zahriyyah berpendapat bahwa wakaf harus di berikan selamanya (permanen) dan harus diserahkan statemen yang jelas untuk itu. Pendapat kedua yang menyatakan bahwa wakaf boleh bersifat sementara didukung oleh fuqaha' dari kalangan Hanãbilah, sebagian dari kalangan Ja'fariyyah dan Ibnu Suraij dari kalangan Syãfi'iyyah. Menurut mereka wakaf sementara adalah sah baik dalam jangka panjang maupun pendek. $^{3}$

Apabila seseorang mewakafkan sebidang tanah untuk pemeliharaan tempat pendidikan yang dikelola sebuah lembaga misalnya, maka sejak diikrarklan sebagai benda wakaf tanah tersebut menjadi hak Allah dan merupakan amanat bagi lembaga tersebut untuk mengelola dan memelihara tanah itu agar dipergunakan sebaik-baiknya. Menurut Abu Hanifah yang dijadiklan wakaf hanya manfaat dari benda itu namun benda pokoknya masih tetap menjadi milik wakif atau disebut wakaf dalam bentuk pinjaman, dan wakif tersebut dapat mengambil kembali benda waklaf itu sesuai dengan batas waktu yang ditentukan ${ }^{4}$.

\footnotetext{
${ }^{1}$ Ahmad Rofiq, Hukum Islam di Indonesia, cet. VI, Jakarta: Raja Grafindo Peresada, 2003. hlm 480

${ }^{2}$ Ibid. hlm. 481

3 Abdul Ghofur Ansori,Hukum dan Praktik Perwakafan di Indonesia, Yogyakarta; Pilar Media, 2005 hlm. 29

4 Abu Bakr Muhammad ibn Ahmad ibn Abu Sahl as Sarkhasi, al Mabsuth (Ardan :Baitul Afkar al Dauliyah, 2009) jilid II, hlm 1495
} 
Pemanfaatan terhadap harta wakaf tidak bisa dilepaskan dari bentuk harta yang diwakafkan. Menurut sejarah, pemanfaatan harta wakaf pada zaman Nabi Muhammad SAW masih sangat sederhana,karena pada masa itu harta yang diwakafkan hanya berupa tanah dan bangunan.lalu pada perkembangan selanjutnya tepatnya pada masa Muãwwiyyah dan 'Abbãsiyyah pemanfaatan terhadap harta wakaf mulai berkembangMenurut hasan Langulung, abad ke 8 dan 9 Hijriyah selain menjadi zaman kejayaan Islam juga dipandang sebagai zaman keemasan wakaf. Pada saat itu wakaf meliputi berbagai benda seperti masjid, sekolah, tanah pertanian, rumah, toko, kebun dan lain sebagainya.saat itu harta wakaf tidak hanya menyediakan layanan gratis bagi yang tidak mampu tapi juga sebagai penghasil dana seperti pasar yang dapat menghasilkan uang sewa ${ }^{5}$.

Menurut catatan sejarah wakaf dalam ajaran Islam,penghasilan yang bersumber dari harta wakaf disalurkan untuk:

1) Masjid, penghasilan dari harta wakaf paling sering adalah diperuntukkan untuk masjid yang termasuk didalamnya adalah imam, para guru ngaji dan juga khatib.

2) Pendidikan, dalam hal ini menempati urutan yang kedua setelah masjid,dalam penyaluran hasil wakaf untuk pendidikan biasanya digunakan untuk membuat perpustakaan, gaji bagi guru, pembelian buku, beasiswa bagi yang kurang mampu dan kepada yang berprestasi serta penelitian ilmiah.

3) Orang-orang miskin, mereka yang membutuhkan, dalam hal ini termasuk juga pembangunan rumah sakit serta layanan gratis bagi orang yang kurang mampu. ${ }^{6}$

Wakaf produktif merupakan sebuah paradigma baru dalam dunia perwakafan ${ }^{7}$. Dalam ilmu manajemen terdapat salah satu mata kuliah yang disebut manajemen Produksi, produksi berarti proses pengubahan untuk menambah nilai atau manfaat lebih. Konsep dari wakaf produktif pada dasarnya dilandasi oleh ketidapuasan pihak pemerintah (terutama Departemen Agama) terhadap pengelolaan harta wakaf yang dilakukan oleh para nazhir yang berjalan sekarang ini.Jika antara konsep produksi dengan ketidakpuasan pemerintah terhadap pengelolaan wakaf yang dilakukan oleh para nazhir, maka akan diperoleh definisi dari wakaf

\footnotetext{
${ }^{5}$ Hasan Langgulung, azaz-azas pendidikan Islam.(Jakarta:al Husna Dzikra,2000) hlm 178

${ }^{6}$ Jhon.L Esposito, The Oxford encyclopedia of the Modern Islamic World, Oxford University Press. hlm135

7 Achmad Djunaidi dan Thobieb al Asyhar, Menuju Era Wakaf Produktif (Jakarta :Mumtaz Publising, 2007)
} 
produktif yaitu transformasi dari pengelolaan yang alami menjadi pengelolaan yang profesional dalam upaya meningkatkan atau menambah manfaat wakaf.

Para 'ulama mažhab sepakat bahwa segala sesuatu yang menetap maupun dapat dipindah seperti mushaf, kitab maupun hewan.namun Abu Hanifah, Abu Yusuf dan sebagian riwayat dari Imam Mãlik menyatakan bahwa hewan tidak boleh diwakafkan.begitu juga menurut jumhur 'ulama sah, mewakafkan segala sesuatu dengan ketentuan harta itu dapat dijual,dapat diambil manfaatnya serta hartanya tidak berkurang?

Hukum dari pada mewakafkan uang merupakan salah satu tema yang dapat menimbulkan perbedaan pendapat diantara para 'ulama mažhab, dalam khazanah Fiqh Hanafi, Muhammad ibn Abdillah Al 'Anshori memanfaatkan tentang diperbolehkannya wakaf uang dan dalam bentuk barang yang ditimbang seperti gandum, fatwa ini sebenarnya awalnya terkesan aneh bahkan dikalangan penganut mažhab Hanafi, sebab bagaimana mungkin mempersewakan wakaf uang karena hal tersebut dapat merubah fungsi uang sebagai alat tukar,bahkan para penganut mažhab hanafi tersebut mempertanyakannya pada Muhammad Ibnu Abdillah Al Anshori:apa yang dapat kami lakukan dengan dana tunai?lalu beliaupun Menjawab: kita investasikan dana ini dengan cara mudhorobah dan labanya kita sedekahkan, lalu kita jual benda makanan itu, dan hasilnya kita putar dengan cara Mudhorobah. ${ }^{10}$

Mažhab Hanafi berpendapat bahwa hukum yang di terapkan berdasarkan 'urf (adat kebiasaan) mempunyai kekuatan yang sama dengan hukum yang di terapkan berdasarkan nash (teks). Cara mewakafkan uang menurut mažhab Hanafi ialah dengan menjadikannya modal usaha dengan cara mudharabah.. Keuntungannya disedekahkan kepada pihak wakaf. ${ }^{11}$

Namun Ibnu 'Abidin berpendapat bahwa wakaf dirham itu menjadi kebiasaan di wilayah Rumawi. Sedangkan di negeri lain tidak menjadi adapt kebiasaan. Atas dasar itu, ia memandang tidak sah.

Dari definisi,dasar hukum, status, dan sasaran serta tujuan dari tanah wakaf inilah muncul pengertian dari wakaf produktif. Wakaf produktif merupakan sebuah paradigma baru dalam dunia perwakafan ${ }^{12}$. Dalam ilmu manajemen terdapat salah satu mata kuliah yang disebut

\footnotetext{
${ }^{8}$ Prof Dr Jail Mubarak, Wakaf Produktif, hlm 15

${ }^{9}$ Sayyid Sabiq,Fiqih Sunnah, jilid III hlm 533

${ }^{10}$ Ibnu Abidin,Hasyiah Radd al Mukhtar (Beirut:dar Kutub,1994),jilid VI,hlm 555-556

11 Wahbah az-Zuhaili, Al-Fiqh al-Islami wa Adillatubu, Damaskus: Dar al-Fikr, 2005, hlm 7610

${ }^{12}$ Achmad Djunaidi dan Thobieb al Asyhar, Menuju Era Wakaf Produktif (Jakarta :Mumtaz Publising,2007)
} 
manajemen Produksi, produksi berarti proses pengubahan untuk menambah nilai atau manfaat lebih. Konsep dari wakaf produktif pada dasarnya dilandasi oleh ketidapuasan pihak pemerintah (terutama Departemen Agama) terhadap pengelolaan harta wakaf yang dilakukan oleh para nazhir yang berjalan sekarang ini. Jika antara konsep produksi dengan ketidakpuasan pemerintah terhadap pengelolaan wakaf yang dilakukan oleh para nazhir, maka akan diperoleh definisi dari Wakaf Produktif yaitu transformasi dari pengelolaan yang alami menjadi pengelolaan yang profesional dalam upaya meningkatkan atau menambah manfaat wakaf ${ }^{13}$.

Dalam Kompilasi Hukum Islam (KHI) dijelaskan bahwa wakaf adalah perbuatan hukum seseorang, kelompok orang, atau badan hukum dengan memisahkan sebagian harta benda miliknya dan melembagakannya untuk selama-lamanya guna kepentingan ibadah atau keperluan umum lainnya sesuai dengan ajaran Islam ${ }^{14}$ Aspek hukum dari wakaf produktif yang tertuang pada undang-undang No 41 Tahun 2004 tentang wakaf dan Peraturan pemerintah No 42 tahun 2006 tentang wakaf.

\section{Pelaksanaan Wakaf di Indonesia}

Sebagai salah satu isnstitusi keagamaan yang erat hubungannya dengan sosial ekonomi, wakaf tidak hanya berfungsi sebagai ibadah ritual semata tapi juga berfungsi sosial. Salah satu macam dari harta wakaf adalah wakaf khairi. wakaf ini dalam masyarakat sekarang dikenal sebagai wakaf sosial, karena wakaf ini diberikan oleh orang yang mewakafkan agar manfaat dari harta wakaf dapat dinikmati oleh kalangan masyarakat secara umum, contohnya, mewakafkan tanah untuk mendirikan masjid, mewakafkan kebun yang hasilnya dimanfaatkan untuk membina suatu pengajian dan sebagainnya ${ }^{15}$.

Wakaf dapat dijadikan sebagai sumber abadi umat. Apabila umat memiliki sumber daya abadi tentunya dana yang diperoleh dapat dipergunakan sebagai sumber abadi keuangan masjid, surau atau sekolah, selain itu dana dari wakaf tersebut dapat dipergunakan untuk membantu biaya pendidikan, seperti beasiswa untuk anak-anak tidak mampu.membangun klinik kesehatan atau rumah sakit gratis untuk orang miskin ${ }^{16}$.

\footnotetext{
13 Prof Dr Jail Mubarak, Wakaf Produktif, hlm 15

${ }^{14}$ Kompilasi Hukum Islam, bab I, pasal 215,ayat (1)

15 Depag, Fiqih Wakaf (Jakarta :Direktorat Jendral Bimas dan Penyelenggaraan Haji, 2003) hlm 16

${ }^{16}$ Suhrawardi K lubis, Wakaf \&Pemberdayaan Umat. hlm 109
} 
. Ia merupakan bentuk pernyataan iman yang mantap dan rasa solidaritas yang tinggi antar sesama manusia. Oleh karenanya, wakaf adalah salah satu usaha mewujudkan dan memelihara hubungan vertikal (hablun min Allah) dan horizontal (bablun min al-nas). Dalam fungsinya sebagai ibadah ia di harapkan akan menjadi bekal bagi kehidupan si wakif (orang yang berwakaf) di hari kemudian (akhirat). Ia adalah suatu bentuk amal yang pahalanya akan terus mengalir selama harta wakaf di manfaatkan. Rasulullah SAW bersabda didalam sebuah hadist

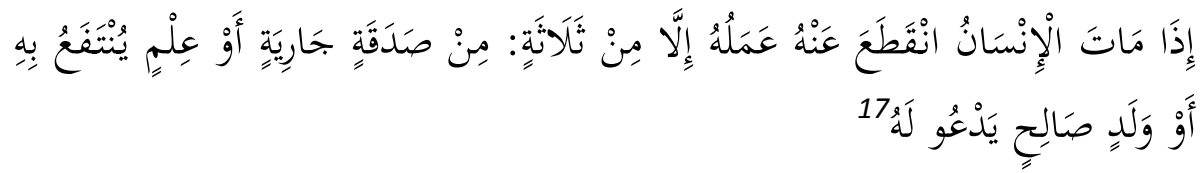

Artinya: "Apabila manusia wafat, terputuslah amal perbuatannya, kecuali tiga bal, yaitu sedekah jariyah, atau ilmu pengetahuan yang di manfaatkan, atau anak yang saleb".

Para 'ulama menafsirkan sabda Rasulullah SAW : (sedekah jariyah) dengan wakaf. Dalam fungsi sosialnya, wakaf merupakan aset yang amat bernilai dalam pembangunan sosial yang tidak memperhitungkan jangka waktu dan keuntungan materi bagi orang yang mewakafkan. Kenyataan telah membuktikan bahwa pada mayoritas Negara Islam, wakaf merupakan sumber dana yang potensial.

Pemanfaatan terhadap harta wakaf tidak bisa dilepaskan dari bentuk harta yang diwakafkan.Menurut sejarah, pemanfaatan harta wakaf pada zaman Nabi Muhammad SAW masih sangat sederhana,karena pada masa itu harta yang diwakafkan hanya berupa tanah dan bangunan.lalu pada perkembangan selanjutnya tepatnya pada masa Muãwwiyyah dan 'Abbãsiyyah pemanfaatan terhadap harta wakaf mulai berkembang Menurut Hasan Langulung,abad ke 8 dan 9 Hijriyah selain menjadi zaman kejayaan Islam juga dipandang sebagai zaman keemasan wakaf. Pada saat itu wakaf meliputi berbagai benda seperti masjid,sekolah,tanah pertanian,rumah,toko,kebun dan lain sebagainya.saat itu harta wakaf tidak hanya menyediakan layanan gratis bagi yang tidak mampu tapi juga sebagai penghasil dana seperti pasar yang dapat menghasilkan uang sewa $^{18}$

Tugas nazhir secara umum adalah menjaga ,merawat,dan mendistribusikan harta wakaf kepada segala pihak yang berhak,dan dia harus mencurahkan segala pikiran dan tenaga agar hasil harta wakaf semakin berkembang ${ }^{19}$

\footnotetext{
${ }^{17}$ Muslim,Shahih Muslim, (Beirut Dar al Fikr, 1992) Juz II hlm 70.

${ }^{18}$ Hasan Langgulung, azaz-azas pendidikan Islam.(Jakarta:al Husna Dzikra,2000) hlm 178

${ }^{19}$ Abd ar-Rauf al-Manawi asy-Syafi'i, Kitab Taisir al-Wuquf, Riyadh: Maktabah Nazar Mustafa al-Baz, 1998 hlm 136
} 
Dengan melihat realitas status dan kedudukan nazhir di dalam praktek perwakafan tanah khususnya di tengah tengah kehidupan masyarakat terlihat begitu penting dalam rangka tetap terjaganya kelestarian harta wakaf itu sendiri. ia berfungsi sebagai administator yang diserahi dan diberi amanat untuk mengelola dan untuk memelihara, dan mengurusnya. Ia juga sebagai kuasa yang mewakili harta wakaf yang dikelolanya di dalam dan diluar hukum.

Namun ketika dihadapkan pada realita di lapangan, penulis mendapati bahwa pada zaman sekarang ini ternyata makin banyak orang yang tidak dapat dipercaya. Atau ketika harta tersebut di wakafkan tidak adanya pihak selain wakif, nazhir dan 2 orang saksi, padahal dengan adanya pengukuhan yang diterbitkan dalam bentuk akta atau nazhir dipilih oleh Badan wakaf indonesia maka keselewangan wewenang terhadap harta wakaf dapat diminimalisir.

Meskipun sertifikasi tanah wakaf dalam pandangan masyarakat awam dianggap tidak penting namun menurut sistem peraturan perundang-undangan yang berlaku di Negara Indonesia bahwa di dalam berikrar di hadapan Penjabat Pembuat Akta Ikrar Wakaf, Wakif disyaratkan menyampaikannya kepada Nazhir. Latar belakangnya adalah sebagai salah satu alat pembuktian dari pada wakafnya itu sendiri, sehingga kehawatiran terhadap penyelewengan harta wakaf dapat diminimalisir seperti kasus-kasus yang terjadi di desa Megaluh.

Menurut catatan sejarah wakaf dalam ajaran Islam, penghasilan yang bersumber dari harta wakaf disalurkan untuk :

1. Masjid, penghasilan dari harta wakaf paling sering adalah diperuntukkan untuk masjid yang termasuk didalamnya adalah imam, para guru ngaji dan juga khatib.

2. Pendidikan, dalam hal ini menempati urutan yang kedua setelah masjid, dalam penyaluran hasil wakaf untuk pendidikan biasanya digunakan untuk membuat perpustakaan, gaji bagi guru, pembelian buku, beasiswa bagi yang kurang mampu dan kepada yang berprestasi serta penelitian ilmiah.

3. Orang-orang miskin, mereka yang membutuhkan, dalam hal ini termasuk juga pembangunan rumah sakit serta layanan gratis bagi orang yang kurang mampu. ${ }^{20}$

Dan ketika wakif hendak mewakafkan sesuatu pada nazhir hendaklah disyaratkan mengucapkan shighat (ikrar). Ikrar wakaf ialah pernyataan kehendak wakif yang diucapankan secara lisan dan/atau tulisan kepada Nazhir untuk mewakafkan harta benda miliknya.

${ }^{20}$ Jhon. L Esposito, The Oxford encyclopedia of the Modern Islamic World, Oxford University Press. hlm 135 
Karena ternyata disinilah nanti juga yang menjadi inti permasalahan dari ketidaktahuannya seseorang bahwa harta tersebut telah di wakafkan dan tidak akan terjadi yang namanya pengambil alihan paksa dikarenakan tidak adanya legalitas yang jelas. Ikrar wakaf cukup dengan ijab saja dari wakif tanpa memerlukan qobul dari mauquf 'alaih, sebagaimana dikatakan Zakariyya al-Anshori dalam Fath al-Wahab ${ }^{21}$

Maka tidak disyaratkan adanya qobul, walaupun dari sesuatu yang nyata jelasnya, karena sesungguhnya wakaf adalah ibadah untuk mendekatkan diri kepada Allah".

Pernyataan tersebut menunjukkan, bahwa ikrar wakaf merupakan tindakan hukum yang bersifat deklaraitif (sepihak). Untuk itu, tidak diperlukan adanya qobul dari orang yang menikmati manfaat wakaf. Karena fungsi dari ibadah wakaf adalah pendekatan diri kepada Allah SWT. berikut :

Para fuqaha' telah menetapkan syarat-syarat shighat (ikrar), sebagai

1. Shighat harus mengandung pernyataan bahwa wakaf itu bersifat kekal (ta'bid). Untuk itu wakaf yang dibatasi waktunya tidak sah. Lain halnya mažhab Mãliki yang tidak mensyaratkan ta'bid sebagai syarat sah wakaf; ${ }^{22}$

2. Shighat harus mengandung arti yang tegas dan tunai; ${ }^{23}$

3. Shighat harus mengandung kepastian, dalam arti suatu wakaf tidak boleh diikuti oleh syarat kebebasan memilih; dan

4. Shighat tidak boleh dibarengi dengan syarat yang membatalkan, seperti mensyaratkan barang tersebut untuk keperluan maksiat. Adapun dalam hal pengucapan dan/atau tulisannya.

Menurut sistem peraturan perundang-undangan yang berlaku bahwa di dalam berikrar di hadapan Penjabat Pembuat Akta Ikrar Wakaf, Wakif disyaratkan menyampaikannya kepada nazhir. Tentu latar belakang dari persyaratan ini adalah demi tetap terjaminnya kelestarian harta wakafnya itu sendiri dan di dalam penyampaian ikrarnya tersebut kepda Nazhir disyaratkan pula harus disaksikan oleh setidak-tidaknya dua orang saksi $^{24}$. Latar belakangnya adalah sebagai salah satu alat pembuktian dari pada wakafnya itu sendiri.

\footnotetext{
${ }^{21}$ Abu Yahya Zakariya al-Anshori, Fath al-Wahab, Juz I, Semarang: Toha Putra, t.th., hlm, 257.

22 Wahbah Zuhaili, op. cit., hlm, 196

${ }^{23}$ Ibid. hlm 196

${ }^{24}$ Undang-undang Republik Indonesia No.41 Pasal 17 tahun 2004 tentang Wakaf
} 
Berdasarkan analisa terhadap ketentuan-ketentuan diatas, bahwa dalam pemberian harta wakaf harus memenuhi ketentuan seperti harus di ucapkannya ikrar agar terjamin adanya bukti yang jelas akan adanya harta yang akan di wakafkan.

Di dalam perwakafan sendiri nazhir mempunyai peranan yang sangat penting. Agar Nazhir yang bersangkutan dapat menjalankan fungsinya sebagaimana mestinya, maka baik Nazhir yang berbentuk kelompok perorangan maupun yang berbentuk badan hukum memerlukan berbagai persyaratan tertentu yang harus dipenuhinya. Syarat-syarat dimaksud bagi Nazhir kelompok perorangan adalah sebagai berikut:

1. Warga negara Republik Indonesia

2. Beragama Islam

3. Sudah dewasa

4. Sehat jasmani dan rohani

5. Tidak berada dibawah pengampuan, dan

6. Amanah. ${ }^{25}$

Selain itu baik Nazdir yang berbentuk kelompok perorngan maupun yang berbentuk suatu badan hukum harus terdaftar di Kantor Urusan Agama (KUA) kecamatan setempat untuk mendapatkan pengesahan dari padanya. Pendaftaran dan pengesahan ini dimaksudkan untuk menghindari terjadinya suatu perbuatan perwakafan yang menyimpang dari ketetntuan yang telah ditetapkan dan untuk mempermudah pengawasan.

Pengesahan dimaksud harus dituangkan secara tertulis yang antara lain memuat

a. Pernyataan pengesahan Nazdir untuk suatu desa atau kelurahan tertentu

b. Identitas lengkap dari seluruh anggota Nazdir serta kedudukan masing-masing di dalam kelompok kenazdirannya. ${ }^{26}$

Sebelum pengesahan, terlebih dahulu ia Kepala Kantor Urusan Agama (KUA) yang bersangkutan, meminta/mendengar saran dari camat dan Majelis 'ulama Kecamatan ${ }^{27}$.

Berdasarkan analisa dari Hukum positif diatas bahwa undangundang juga telah menyeleksi secara ketat terhadap para Nazhir namun, dalam kenyataanya ternyata di Desa Megaluh sendiri pemilihan nazhir hanya berdasarkan penunjukan tanpa adanya syarat yang harus dipenuhi dikaibatkan kurang adanya komunikasi anta PPN, pegawai KUA dan sang Wakif sendiri.

\footnotetext{
${ }^{25} \mathrm{Ibid}$

${ }^{26}$ Ibid, Pasal 14

${ }^{27}$ pasal 219 ayat (3) Kompilasi Hukum Islam
} 
Dan disinilah yang menjadi letak kesalahan dari sistem pengelolaan wakaf di Desa Megaluh karena berdasarkan penelitian penulis semua harta wakaf yang berupa sawah atau tanah yang dapat dikelola dan diambil manfatnya ternyata belum mempunyai akta ikrar wakaf sehingga legalitas dari harta wakaf itu tidak dapat terjamin dengan baik dan benar.

\section{Analisa Hukum Islam dan Hukum positif terhadap Pengembangan Wakaf Produktif}

Pada masa sekarang ini tidak dapat dipungkiri bahwa sebagian besar rumah ibadah, perguruan Islam maupun lembaga-lembaga yang bernafaskan Islam dibangun diatas tanah wakaf, sehingga tidak sedikit pula dana dari penghasilan harta wakaf itu disalurkan untuk kepentingan masyarakat umum, seperti:memberikannya pada orang miskin, lembaga pendidikan serta untuk layanan kesehatan secara gratis bagi masyarakat yang kurang mampu.

Dengan demikian, harta wakaf telah memainkan peranan pentingdalam pembanguna masyarakat islam, hal ini tidak terlepas dari inti ajaran yang terkandung dari wakaf tersebut yaitu semakin banyak manfaat wakaf dapat dinikmati masyarakat luas,maka semakin besar pula pahala yang mengalir pada orang yang mewakafkan.

Dalam membantu dan menunjang kesejahteraan umat ,al Qur'an telah meletakkan sebuah fondasi yang kuat, terutama dalam hal yang menyangkut wakaf agar harta yang dimiliki oleh tiap muslim tidak hanya berkutat pada orang kaya saja. Hal ini seperti yang telah tertulis pada Al Qur'an Surat Al Hasyr ayat 7 :

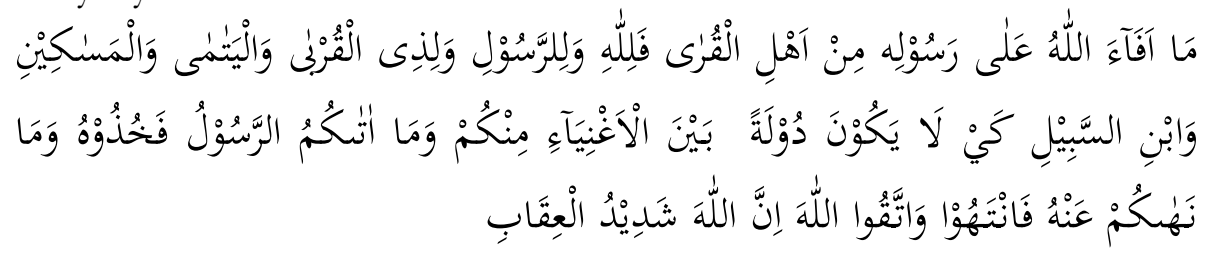

Apa saja (harta yang diperoleh tanpa peperangan) yang dianugerabkean Allab kepada Rasul-Nya dari penduduk beberapa negeri adalah untuk. Allah, Rasul, kerabat (Rasul), anak yatim, orang miskin, dan orang yang dalam perjalanan. (Demikian) agar harta itu tidak. hanya beredar di antara orang-orang kaya saja di antara kamu. Apa yang diberikan Rasul kepadamu terimalah. Apa yang dilarangnya bagimu tinggalkanlah. Bertakwalah kepada Allah. Sesunggubnya Allah sangat keras hukumanNya. ${ }^{28}$.

${ }^{28}$ Depag RI, al-Qur'an dan Terjemahan (Semarang: Toha Putra,1995) 
Ayat diatas secara tersirat jelas menghendaki agar harta yang dimiliki oleh orang yang mampu tidak tersebar hanya kepada seseorang tertentu melainkan dapat dimiliki secara menyeluruh oleh umat Islam.

Prinsip ajaran Islam yang ada pada sistem zakat, infaq, shodaqah serta wakaf yaitu berisi anjuran untuk menyisihkan sebagian rizki yang telah diberikan Allah agar dialokasikan kepada orang fakir, miskin, serta orang-orang yang lemah.Dan kalau kehendak wahyu ilahi ini dibumikan oleh pihak-pihak terkait, maka kesenjangan sosial sebagai jurang pemisah antara yang kaya dan miskin tidak akan terjadi. ${ }^{29}$

Wakaf adalah salah satu pondasi yang penting untuk membangun kesejahteraan bagi umat Islam,selama ini wakaf hanya seperti pasai yang berada di tengah masyarakat pada masa sekarang ini, misalkan ,ada seseorang atau lembaga mewakafkan sebidang tanah dengan tujuan agar digunakan untuk tempat pembangunan rumah ibadah, kemudian seiring berjalannya waktu kemudian dibangunlah sebuah rumah ibadah diatas tanah wakaf tersebut, padahal kalau nazhir atau pengelola dari tanah wakaf tersebut dapat berperan aktif dalam mengembangkan tanah tersebut untuk aset usaha seperti pasar dan lain-lain dengan tanpa menghilangkan fungsi peruntukannya.

Sebagaimana deskripsi data yang telah penulis berikan pada bab sebelumnya,ada dua permasalahan hukum dalam praktek pengelolaan dan pengembangan wakaf yang terjadi di Desa Megaluh yang dapat dikaji melalui Hukum Islam yang berupa Syariat atau ketentuan 'ulama mažhab dan ketentuan yang diatur oleh undang-undang yang tertuang dalam Kompilasi Hukum Islam.

Dalam literatur fikih klasik, cara yang banyak ditempuh dalam mengembangkan harta wakaf ialah dengan jalan mempersewakannya. Hal ini sejalan dengan kenyataan bahwa kebanyakan harta wakaf dalam bentu harta tetap (fixed Asset), seperti lahan pertanian dan bangunan.

Hukum dari pada mewakafkan uang merupakan salah satu tema yang dapat menimbulkan perbedaan pendapat diantara para 'ulama mažhab,dalam khazanah Fiqh Hanafi, Muhammad ibn Abdillah Al Anshori memfatwatkan tentang diperbolehkannya wakaf uang dan dalam bentuk barang yang ditimbang seperti gandum, fatwa ini sebenarnya awalnya terkesan aneh bahkan dikalangan penganut mažhab Hanafi, sebab bagaimana mungkin mempersewakan wakaf uang karena hal tersebut dapat merubah fungsi uang sebagai alat tukar, bahkan para penganut mažhab hanafi tersebut mempertanyakannya pada Muhammad ibn abdillah Al Anshoriapa yang dapat kami lakukan dengan dana

${ }^{29}$ Farid Wadjdy dan Mursyid, Wakaf dan Kesejahteraan Umat: cet I(Yogyakarta:Pustaka Pelajar, 2007) hlm 78 
tunai?lalu beliaupun Menjawab:kita investasikan dana ini dengan cara mudhorobah dan labanya kita sedekahkan, lalu kita jual benda makanan itu, dan hasilnya kita putar dengan cara Mudhorobah. ${ }^{30}$

Dalam mažhab Hanafi,seperti yang telah dijelaskan oleh Ibnu Abidin tentang kebolehan wakaf uang bergantung pada adat istiadat yang berlaku di suatu tempat ${ }^{31}$. Sedang Ibnu taimiyyah meriwayatkan bahwa ada satu pendapat dari mažhab Hanbali yang memperbolehkan wakaf dalam bentuk uang ${ }^{32}$

Ibnu Qudamah merupakan salah satu dari sekian 'ulama yang kontra dengan kebolehan wakaf uang. Beliau meriwayatkan bahwa sebagian besar kalangan 'ulama tidak memperbolehkan wakaf uang dengan alasan ketika di bayarkan akan lenyap. Di samping itu, beliau juga menjelaskan bahwa mempersewakan uang adalah ilegal dalam syara', sehingga wakaf uangpun tidak di anggap sah. Mereka beralasan dengan mempersewakan uang untuk di tarik manfaatnya berarti telah merubah fungsi uang sebagai alat tukar. ${ }^{33}$

Adapun sebagai landasan dari diperbolehkannya wakaf ini adalah fatwa dari Majlis 'Ulama Indonesia yang bersandar dari pendapat para 'ulama,yaitu:

a. Pendapat 'Ulama Az Zuhri bahwa mewakafkan dinar hukumnya boleh ,dengan cara menjadikan dinar tersebut sebagai modal usaha yang keuntungannya disalurkan pada mauquf alaih

b. Pendapat 'ulama mutaqaddimin dari kalangan hanafi memperbolehkan wakaf uang atas dasar istibsan bil urf

c. Pendapat dari sebagaian mažhab Syãfi'i yakni Abu Tsaur yang meriwayatkan boleh wakaf berupa uang ${ }^{34}$

Adapun Fatwa MUI adalah :

1) Wakaf uang adalah wakaf yang dilakukan seorang atau sekelompok orang atau lembaga atau badan hukum dalam bentuk uang tunai .

2) Termasuk dalam wakaf ini adalah surat-surat berharga

3) Wakaf uang hukumnya boleh

Dewasa ini terbuka kesempatan untuk berwakaf dalam bentuk uang. Tapi persoalannya, bagaimana memanfaatkan dana wakaf yang terhimpun?. Menurut Muhammad Abdullah al-Anshori, "Uang wakaf akan bermanfaat jika ia difunakan, untuk itu kita investasikan dana terebut dan labanya kita

\footnotetext{
${ }^{30}$ Ibnu Abidin,Hasyiah Radd al Mukhtar (Beirut:dar Kutub,1994),jilid VI,hlm 555-556

${ }^{31}$ Ibnu Abidin ,Loc it.hlm 555-567

32 Ibnu Taimiyyah ,Majmu’ Al Fatawa,hlm 210

${ }^{33}$ Ibnu Qudamah, Al-Mughn wa Syarah Al-Kabir (Beirut:dar Al-Kutub) hlm 235

34 Suhrawardi K lubis, Wakaf \&Pemberdayaan Umat.jakarta hal 109
} 
sedekahkan". Hal yang sama juga di ungkapkan oleh Imam az-Zuhri (wafaat tahun $124 \mathrm{H}$ ), sebagaimana di riwayatkan oleh Imam Bukhori ${ }^{35}$."'

Muncul dan berkembangnya lembaga-lembaga keuangan syariah dengan prinsip kerjasama bagi hasil, prinsip jual beli, dan prinsip sewa menyewa. Maka semakin mempermudah pengelola wakaf (Nazhir) selaku manajemen investasi untuk menginvestasikan dana-dana wakaf yang terhimpun sesuai dengan prinsip-prinsip syariat Islam. Adapun diantara bentuk-bentuk investasi yang dapat di lakukan oleh pengelola wakaf (Nazhir) ialah sebagai berikut:

1. Investasi Mudharabah

Investasi mudharabah merupakan salah satu alternatif yang ditawarkan oleh produk keuangan syari'ah guna mengembangkan harta wakaf. Salah satu contoh yang dapat dilakukan oleh pengelola wakaf dengan sistem ini ialah membangkitkan sektor usaha kecil dan menengah dengan memberikan modal usaha kepada petani gurem, para nelayan, pedagang kecil dan menengah (UKM). Dalam hal ini pengelola wakaf uang berperan sebagai shohibul mal (pemilik modal) yang menyediakan modal 100\% dari usaha/proyek dengan sistem bagi hasil.

2. Investasi Musyärakab ${ }^{36}$

Alternatif investasi lainnya ialah investasi dengan sistem musyãrakah. Investasi ini hampir sama dengan investasi mudharabah. Hanya saja pada investasi musyãrakah ini risiko yang ditanggung oleh pengelola wakaf lebih sedikit, oleh karena modal ditanggung secara bersama oleh dua pemilik modal atau lebih. Investasi ini memberikan peluang bagi pengelola wakaf untuk menyertakan modalnya pada sektor usaha kecil menengah yang di anggap memiliki selayaknya usaha namun kekurangan modal untuk mengembangkan usahanya.

3. Investasi Ijärah ${ }^{37}$

Salah satu contoh yang dapat dilakukan dengan sistem investasi ijãrah (sewa) ialah mendayagunakan tanah wakaf yang ada. Dalam hal ini pengelola wakaf menyediakan dana untuk mendirikan bangunan di atas tanah wakaf, seperti pusat perbelanjaan (Commercial Center), rumah sakit, apartemen dll. Kemudian pengelola harta wakaf menyewakan gedung tersebut hingga dapat menutup modal pokok dan mengambil keuntungan yang dikehendaki.

\footnotetext{
35 Bukhori, Shohih Bukhari, (Dar al fikr ; Beirut, 1994/1414), Juz III, h.259-260.lihat juga, Abu As Su'ud Muhammad, Risalatu Fi Jawazi Waqfi An Nuqud, (Beirut; Dar Ibnu Hazm, 1997), h.13

${ }^{36}$ Investasi Musyãrakah ialah kontrak yang dilakukan oleh 2 pemilik modal atau lebih untuk menyatukan modalnya pada usaha tertentu, sedangkan pelaksanaannya bisa di tunjuk salah satu dari mereka.

${ }^{37}$ Investasi ijarah ialah kontrak (akad) sewa menyewa antara dua pihak.
} 


\section{Investasi Murãbahab3 ${ }^{38}$}

Dalam investasi murãbahah, pengelola wakaf diharuskan berperan sebagai enterpreneur (pengusaha) yang membeli peralatan dan material yang diperlukan melalui suatu kontrak murãbahah. Adapun keuntungan dari investasi ini adalah pengelola wakaf dapat mengambil keuntungan dari selisih harga pembelian dan penjualan. Manfaat dari investasi ini ialah pengelola wakaf dapat membantu pengusaha-pengusaha kecil yang membutuhkan alat-alat produksi, misalnya tukang jahit yang memerlukan mesin jahit.

Berdasarkan penelitian yang dilakukan penulis di Desa Megaluh ternyata tidak ditemukan suatu investasi akan harta wakaf, hal ini dikarenakan kurangnya pengetahuan masyarakat awam tentang pentingnya harta wakaf sebagai sumber dana bagi umat Islam

\section{Kesimpulan}

Pengembangan harta wakaf produktif adalah dengan menjadikan harta wakaf tersebut modal usaha dan kemudian menyalurkannya sebagai wakaf, adapun cara mengembangkan harta wakaf menurut fiqh Islam adalah dengan menginvestasikan harta benda tersebut baik dengan cara mudlorobah yaitu dengan akad kerja sama dengan menjadikan harta tersebut dalam bentuk aset sehingga aset tersebut dapat dikembangkan secara optimal atau dengan cara Ijãrah yaitu disewakan dalam hal ini sang penyewa akan mendapatkan keuntungan yang nantinya hasil dari akad tersebut dikembalikan pada di mana harta wakaf tersebut diperuntukan.

38 Murabahah ialah jual beli dimana keuntungan disepakati antara penjual dan pembeli 


\section{DAFTAR PUSTAKA}

al-Anshori, Abu Yahya Zakariya. t.th. Fath al-Wahab, Juz I, Semarang: Toha Putra.

al-Bukhari, Muhammad bin Isma'il bin Ibrahim., 1994/1414. Shobih Bukhari, Juz III, Dar al fikr ; Beirut.

al-Naisaburi, Abul Husain Muslim bin al-Hajjaj,. 1992. Shabih Muslim, Juz II, Beirut : Dar al Fikr.

as-Sarkhasi, Abu Bakr Muhammad ibn Ahmad ibn Abu Sahl. 2009. al Mabsuth, jilid II, Ardan :Baitul Afkar al Dauliyah.

asy-Syafi'I, Abd ar-Rauf al-Manawi., 1998. Kitab Taisir al-Wuquf, Riyadh:

Maktabah Nazar Mustafa al-Baz

Abidin, Ibnu. 1994. Hasyiah Radd al Mukhtar, jilid VI, Beirut: dar alKutub.

Ansori, Abdul Ghofur. 2005. Hukum dan Praktik Perwakafan di Indonesia,Yogyakarta; Pilar Media.

Departemen Agama RI. 2003. Fiqih Wakaf, Jakarta :Direktorat Jendral Bimas dan Penyelenggaraan Haji. ,1995. al-Qur'an dan Terjemahan (Semarang: Toha Putra.

Djunaidi, Achmad, dan Thobieb al Asyhar. 2007. Meniju Era Wakaf Produktif, Jakarta :Mumtaz Publising.

Esposito, Jhon. L., 1995. The Oxford encyclopedia of the Modern Islamic World,Oxford University Press.

Kompilasi Hukum Islam di Indonesia

Langgulung, Hasan. 2000. а₹а₹-azas pendidikan Islam, Jakarta:al Husna Dzikra.

Lubis, Suhrawardi K, Dkk., 1993. Wakaf \& Pemberdayaan Umat, Jakarta:

Sinar Grafika.

Mubarok, Jaih. 2016. Wakaf Produktif, Jakarta: Simbiosa Rekatama Media.

Muhammad, Abu As Su'ud. 1997. Risalatu Fi Jawazi Waqfi An Nuqud,

Beirut; Dar Ibnu Hazm.

Qudamah, Ibnu. 1997. Al-Mughn wa Syarah Al-Kabir, Beirut: dar AlKutub.

Rofiq, Ahmad. 2003. Hukum Islam di Indonesia, cet. VI, Jakarta: Raja Grafindo Persada.

Sabiq, Sayyid. 2017. Fiqih Sunnah, jilid III, Jakarta: Republika Penerbit. Taimiyyah, Ibnu. t.th. Majmu' al-Fatawa, VCD. Maktabah Syamilah. 
Undang-undang Republik Indonesia No 41 tahun 2004 tentang Wakaf Wadjdy, Farid. dan Mursyid, 2007. Wakaf dan Kesejabteraan Umat.,cet I, Yogyakarta:Pustaka Pelajar.

Zuhaili, Wahbah, 2005. Al-Fiqh al-Islami wa Adillatuhu, Damaskus: Dar alFikr 
